\title{
ALTERNATIVE MANAGEMENT OF A PROBLEMATIC WEED OF WHEAT Avena fatua L. BY METABOLITES OF Trichoderma
}

\author{
Arshad Javaid ${ }^{1 *}$, and Sajjad Ali ${ }^{1}$
}

\begin{abstract}
Wild oat (Avena fatua L.) is a problematic weed of wheat (Triticum aestivum L.) in Pakistan. The present study was designed to evaluate the herbicidal activity of culture filtrates of four Trichoderma spp., namely T. harzianum, T. pseudokoningii, T. reesei and T. viride, against this weed species. In a laboratory bioassay, original (100\%) and diluted (50\%) culture filtrates of T. harzianum and T. pseudokoningii significantly reduced shoot and root growth of A. fatua seedlings. Only original culture filtrates of $T$. reesei exhibited significant effects, while the effect of filtrates of T. viride was insignificant against shoot and root growth of the target weed species. Generally, original concentrations of culture filtrates of all Trichoderma spp., except $T$. harzianum, significantly reduced various parameters of root and shoot growth of wheat seedlings. In foliar spray bioassay, pot-grown 1-wk and 2-wk old A.fatua and wheat seedlings were sprayed with $100 \%$ culture filtrates of the four Trichoderma spp. thrice with $5 \mathrm{~d}$ interval each. Culture filtrates of all except $T$. viride significantly diminished root and shoot biomass of A. fatua plants in 1-wk old plants. The effect of foliar spray on root and shoot growth of wheat was insignificant. Present study concludes that metabolites of $T$. harzianum, T. reesei and T. pseudokoningii contain herbicidal constituents for the management of A. fatua .
\end{abstract}

Key words: Alternative herbicides, Avena fatua, fungal metabolites, Trichoderma spp.

$\mathrm{I}$ $\mathrm{n}$ the literature, there are many examples of fungal products having herbicidal activities. AAl-toxin is a phytotoxin produced by Alternaria alternata (Fr.) Keissl. pathovars that infect tomato. Its mode of infection was reported to be inhibition of RNA synthesis. It is active on many weed species (Abbas et al., 1995). Two phytotoxic metabolites prehelminthosporal and dihydropore, were isolated from the cultural filtrates of the fungus Bipolaris sp. showing herbicidal activity against Sorghum halepense (L.) Pers. (Parmar and Devkumar, 1993). Three herbicidal metabolites, 3-hydroxybenzylalcohol, 2-methyl hydroquinone and epiepoformin were isolated from a soil-borne fungus Scopulariopsis brumptii. Similarly, a phytotoxic metabolite trans-4 aminoproline isolated from culture filtrates of Ascochyta caulina was found to be very effective in controlling Chenopodium album (L.) (Evidente et al., 2000). Evidente et al. (2005) isolated a new phytotoxic trisubstituted naphthofuroazepinone from the culture filtrates of Drechslera siccans, named drazepinone, and characterized as a 3,5,12 a-trimethyl2,5,5a,12a-tetrahydro-1 $H$-naphtho[ $\left[2^{\prime}, 3^{\prime}: 4,5\right]$ furo[2,3- $\left.b\right]$

${ }^{1}$ Punjab University Lahore, Institute of Agricultural Sciences, Lahore, Pakistan.

*Corresponding author (arshadjpk2004@yahoo.com).

Received: 8 October 2010.

Accepted: 5 January 2011. azepin-2-one. Assayed at $2 \mu \mathrm{g} \mu \mathrm{L}^{-1}$ solution, the novel metabolite proved to have broad-spectrum herbicidal properties. Phyllosticta cirsii, a fungal pathogen isolated from diseased Cirsium arvense leaves and evaluated as a biocontrol agent of this noxious perennial weed, produces different phytotoxic metabolites with potential herbicidal activity when grown in liquid cultures. Phyllostictines A-D, four novel oxazatricycloalkenones, were isolated from this pathogen (Evidente et al., 2008). Recently Javaid and Adrees (2009) reported that metabolites of Alternaria alternata, Fusarium oxysporum, F. solani, Drechslera hawaiiensis, D. australiensis and D. rostrata were highly effective in controlling the growth of the noxious weed Parthenium hysterophorus.

Trichoderma spp. are among the most frequently isolated soil fungi and present in plant root ecosystems (Harman et al., 2004). To date, most of the studies on Trichoderma spp. have been conducted with respect to their activity as biological control agents. Their efficacy has been demonstrated for the management of nematode and fungal diseases under field conditions (Sahebani and Hadavi, 2008; Hanada et al., 2009). The modes of action as biological control agents include mycoparasitism, antibiosis, competition, enzyme activity and induced plant defense (Howell, 2003). In addition to their role as biocontrol agents, Trichoderma spp. have also been 
used in a wide range of commercial enzyme productions, namely, cellulases, hemicellulases, proteases, and $\beta$-1,3glucanase (Sadhasivam et al., 2008; Kovacs et al., 2009). However, weed control by using Trichoderma spp. is still a relatively unexplored field and the few known studies in this area are restricted to $T$. virens only (Hutchinson, 1999; Heraux et al., 2005). The present study was, therefore, designed to evaluate the herbicidal activity of culture filtrates of four Trichoderma spp.: T. harzianum, T. pseudokoningii, T. reesei and T. viride, against Avena fatua, a problematic weed of wheat.

\section{MATERIALS AND METHODS}

\section{Procurement of Trichoderma species}

Pure cultures of four species of Trichoderma: $T$. harzianum, T.pseudokoningii, T. reesei and T. viride were procured from the Fungal Culture Bank of the Institute of Plant Pathology, University of the Punjab, Lahore, Pakistan. These cultures were maintained on Malt Extract Agar (MEA) medium and stored at $4{ }^{\circ} \mathrm{C}$ in a refrigerator.

\section{Preparation of cultural filtrates of the test fungi}

Malt extract broth medium was autoclaved at $121{ }^{\circ} \mathrm{C}$ in $250 \mathrm{~mL}$ conical flasks at $100 \mathrm{~mL}$ medium in each flask. Flasks were inoculated with $5 \mathrm{~mm}$ agar discs of each of the four test fungi from margins of actively growing fungal colonies. Inoculated flasks were incubated under static conditions at $25^{\circ} \mathrm{C}$ for $4 \mathrm{wk}$. After $4 \mathrm{wk}$, the cultures were filtered through sterilized muslin cloth followed by Whatman filter paper $\mathrm{N}^{\circ} 1$. These filtrates were preserved at $4{ }^{\circ} \mathrm{C}$ in a refrigerator. The cultural filtrates were used within $1 \mathrm{wk}$ of filtration to avoid any contamination or chemical alteration (Javaid and Adrees, 2009).

\section{Laboratory bioassay}

Mature seeds of A. fatua were collected from wheat fields of the University of the Punjab, Quaid-e-Azam Campus Lahore, Pakistan. Seeds were dried in the sun, packed in paper bags and stored at room temperature. Ten seeds of A. fatua and wheat var. Sehr were placed in $9 \mathrm{~cm}$ diameter sterilized Petri plates with sterilized filter papers moistened with $3 \mathrm{~mL}$ of original (100\%) and diluted (50\%) crude fungal extract of different Trichoderma species. The negative control treatment received $3 \mathrm{~mL}$ of sterilized distilled water. Since fungal metabolites were obtained using $2 \%$ malt extract broth, and filtrates were also used as $50 \%$ dilutions. Therefore, two positive control treatments with $3 \mathrm{~mL}$ of $2 \%$ and $3 \mathrm{~mL}$ of $1 \%$ malt extract broth were also included. Each treatment was replicated four times. The Petri plates were arranged in a completely randomized design in a growth room maintained at $18 \pm$ $2{ }^{\circ} \mathrm{C}$ and 10:14 h photoperiod. Plants were harvested after
12 d. Data regarding germination, and root/shoot growth in terms of length and fresh biomass were recorded. Plants were dried at $60{ }^{\circ} \mathrm{C}$ to constant weight and dry weight was recorded (Javaid and Adrees, 2009).

\section{Foliar spray bioassay}

Experiment was conducted in February-March 2009 at the University of the Punjab, Lahore ( $31^{\circ} 57^{\prime} \mathrm{N} ; 74^{\circ} 31^{\prime}$ E) Pakistan. Plastic pots of $8 \mathrm{~cm}$ diameter and $12 \mathrm{~cm}$ deep were filled with $350 \mathrm{~g}$ of sandy loam soil with $0.69 \%$ organic matter, $\mathrm{pH} 7.8, \mathrm{~N} 0.035 \%$, available $\mathrm{P} 6.3 \mathrm{mg}$ $\mathrm{kg}^{-1}$ and available $\mathrm{K} 100 \mathrm{mg} \mathrm{kg}^{-1}$. The micronutrients $\mathrm{B}, \mathrm{Mn}, \mathrm{Fe}, \mathrm{Cu}$ and $\mathrm{Zn}$ were 1.06, 22.8, 10.8, 1.9 and 1.3 $\mathrm{mg} \mathrm{kg}^{-1}$ of soil, respectively. Ten seeds of A. fatua and wheat var. Sehr were sown in each pot. After germination, pots were divided into two sets to perform the foliar spray on 1-wk and 2-wk old seedlings. All the pots were arranged in a completely randomized design under natural environmental conditions.

Original culture filtrates of the four selected Trichoderma species were sprayed on 1-wk and 2-wk old A. fatua and wheat seedlings. Both of the sets were sprayed 3-times with an interval of $5 \mathrm{~d}$. Treatment in a similar manner with distilled water spray served as control. All the plants were harvested after $40 \mathrm{~d}$ growth. Plants were carefully uprooted and washed under tap water. Roots were separated from shoots. Data regarding length and dry biomass of shoot and root were recorded.

\section{Statistical analysis}

All the data were subjected to ANOVA followed by Duncan's Multiple Range Test $(\mathrm{P} \leq 0.05)$ to delineate mean differences (Steel and Torrie, 1980).

\section{RESULTS}

\section{Laboratory bioassay}

The effect of culture filtrates of all the Trichoderma species was insignificant on germination of $A$. fatua seeds (Table 1). Maximum shoot length of $115 \mathrm{~mm}$ was recorded in negative control (water). Decreases in shoot length in $1 \%$ and $2 \%$ malt extract treatments were insignificant. Culture filtrates of all the Trichoderma species, except $T$. viride, significantly reduced shoot length. Highest toxicity was recorded due to the culture filtrate of $T$. pseudokoningii, followed by T. harzianum and T. reesei, respectively. The original culture filtrates (100\%) of T. pseudokoningii, $T$. harzianum, $T$. reese $i$ and $T$. viride reduced the shoot length of $A$. fatua by $80,73,62$ and $11 \%$, respectively; as compared to the negative control (Table 1). Culture filtrates of $50 \%$, as well as $100 \%$, of T. pseudokoningii and $T$. harzianum significantly suppressed shoot fresh and dry biomass of A. fatua as compared to negative 
Table 1. Effect of culture filtrates of four Trichoderma species on germination and growth of Avena fatua in laboratory bioassays.

\begin{tabular}{|c|c|c|c|c|c|c|c|c|}
\hline Fungal species & Concentration & Germination & $\begin{array}{l}\text { Shoot } \\
\text { length }\end{array}$ & $\begin{array}{l}\text { Shoot } \\
\text { fresh } \\
\text { weight }\end{array}$ & $\begin{array}{c}\text { Shoot } \\
\text { dry } \\
\text { weight }\end{array}$ & $\begin{array}{l}\text { Root } \\
\text { length }\end{array}$ & $\begin{array}{c}\text { Root } \\
\text { fresh } \\
\text { weight }\end{array}$ & $\begin{array}{c}\text { Root } \\
\text { dry } \\
\text { weight }\end{array}$ \\
\hline & \multicolumn{2}{|c|}{$\%$} & $\mathrm{~mm}$ & \multicolumn{2}{|c|}{$-\mathrm{mg}-$} & $\mathrm{mm}$ & \multicolumn{2}{|c|}{$-\mathrm{mg}$} \\
\hline Control $\left(\mathrm{H}_{2} \mathrm{O}\right)$ & 0 & $100 \mathrm{a}$ & $115 \mathrm{a}$ & $48 \mathrm{a}$ & $5.5 \mathrm{ab}$ & $196 \mathrm{a}$ & $51 \mathrm{a}$ & $5.1 \mathrm{bc}$ \\
\hline Control (1\% ME) & 0 & $100 \mathrm{a}$ & $108 \mathrm{ab}$ & $43 a$ & $5.9 \mathrm{ab}$ & $161 \mathrm{c}$ & $47 \mathrm{a}$ & $4.9 \mathrm{c}$ \\
\hline Control (2\% ME) & 0 & $100 \mathrm{a}$ & $101 \mathrm{ab}$ & $46 a$ & $6.2 \mathrm{a}$ & $178 \mathrm{~b}$ & $50 \mathrm{a}$ & $5.4 \mathrm{abc}$ \\
\hline \multirow[t]{2}{*}{ T. harzianum } & 50 & $91 \mathrm{a}$ & $47 \mathrm{c}$ & $20 \mathrm{~b}$ & 2.6de & $34 \mathrm{f}$ & $15 \mathrm{bc}$ & $1.9 \mathrm{~d}$ \\
\hline & 100 & $88 \mathrm{a}$ & $31 \mathrm{~cd}$ & $14 \mathrm{~b}$ & $2.0 \mathrm{e}$ & $14 \mathrm{~g}$ & $8 \mathrm{~d}$ & $1.0 \mathrm{~d}$ \\
\hline \multirow[t]{2}{*}{ T. pseudokoningii } & 50 & $100 \mathrm{a}$ & $26 \mathrm{~d}$ & $15 b$ & $2.4 \mathrm{de}$ & $19 \mathrm{~g}$ & $12 \mathrm{~cd}$ & $1.4 \mathrm{~d}$ \\
\hline & 100 & $94 a$ & $23 d$ & $11 \mathrm{~b}$ & $1.7 \mathrm{e}$ & $10 \mathrm{~g}$ & $8 \mathrm{~d}$ & $1.2 \mathrm{~d}$ \\
\hline \multirow[t]{2}{*}{ T.reesei } & 50 & $100 \mathrm{a}$ & $91 b$ & $41 \mathrm{a}$ & $5.3 \mathrm{ab}$ & $112 \mathrm{e}$ & $48 \mathrm{a}$ & $6.1 \mathrm{ab}$ \\
\hline & 100 & $100 \mathrm{a}$ & $44 \mathrm{c}$ & $22 b$ & $3.1 \mathrm{~d}$ & $18 \mathrm{~g}$ & $17 \mathrm{~b}$ & $1.9 \mathrm{~d}$ \\
\hline \multirow[t]{2}{*}{ T. viride } & 50 & $100 \mathrm{a}$ & $103 \mathrm{ab}$ & $40 \mathrm{a}$ & $4.7 \mathrm{bc}$ & $146 \mathrm{~d}$ & $49 a$ & $6.3 \mathrm{a}$ \\
\hline & 100 & $100 \mathrm{a}$ & $102 \mathrm{ab}$ & $48 \mathrm{a}$ & $4.9 \mathrm{bc}$ & $119 \mathrm{e}$ & $48 \mathrm{a}$ & $5.1 b c$ \\
\hline
\end{tabular}

In a column, values with different letters show significant differences as determined by Duncan's Multiple Range Test $(\mathrm{P} \leq 0.05)$.

ME: malt extract.

control. Similarly, the negative effect of $100 \%$ filtrates of T. reesei was significant on shoot fresh and dry biomass. Culture filtrates of $T$. viride, however, failed to exhibit any pronounced effect on shoot biomass of A. fatua (Table 1).

Root length was reduced due to $1 \%$ and $2 \%$ malt extract by 18 and $9 \%$, respectively. Culture filtrates of all four tested Trichoderma species significantly reduced root length. The adverse effects of $T$. pseudokoningii and $T$. harzianum filtrates on root length were more pronounced than the effects of T.reese $i$ and $T$. viride. There was 95,93, 91 and 39\% reduction in root length due to $100 \%$ culture filtrates of T. pseudokoningii, T. harzianum, T. reesei and $T$. viride, respectively, as compared to negative control. Malt extract medium exhibited insignificant effects on root fresh and dry biomass. The effect of culture filtrates of the four Trichoderma species on fresh and dry biomass of roots of A. fatua was generally similar to that observed on root length (Table 1).

None of the treatments exhibited significant effects on germination of wheat seeds. Except for 50\% of culture filtrates of $T$. harzianum, all treatments significantly reduced shoots length as compared to negative control. Similarly, original culture filtrates $(100 \%)$ of all the Trichoderma spp. except $T$. harzianum significantly reduced shoot biomass of wheat seedlings. The effects of culture filtrates of the different Trichoderma species evaluated were in general similar for both root and shoot growth parameters (Table 2).

Table 2. Effect of culture filtrates of four Trichoderma sp. on germination and growth of wheat in laboratory bioassays.

\begin{tabular}{|c|c|c|c|c|c|c|c|c|}
\hline Fungal species & Concentration & Germination & $\begin{array}{l}\text { Shoot } \\
\text { length }\end{array}$ & $\begin{array}{c}\text { Shoot } \\
\text { fresh } \\
\text { weight }\end{array}$ & $\begin{array}{c}\text { Shoot } \\
\text { dry } \\
\text { weight }\end{array}$ & $\begin{array}{c}\text { Root } \\
\text { length }\end{array}$ & $\begin{array}{c}\text { Root } \\
\text { fresh } \\
\text { weight }\end{array}$ & $\begin{array}{c}\text { Root } \\
\text { dry } \\
\text { weight }\end{array}$ \\
\hline & \multicolumn{2}{|c|}{$\%$} & $\mathrm{~mm}$ & \multicolumn{2}{|c|}{$-\mathrm{mg}$} & \multirow{2}{*}{$\begin{array}{l}\mathrm{mm} \\
60 \mathrm{a}\end{array}$} & \multicolumn{2}{|c|}{$\longrightarrow \mathrm{mg}$} \\
\hline Control (water) & 0 & $100 \mathrm{a}$ & $129 a$ & $86 b$ & $25 \mathrm{ab}$ & & $63 a b c$ & $18 \mathrm{ab}$ \\
\hline Control (1\% ME) & 0 & $100 \mathrm{a}$ & $97 \mathrm{de}$ & $65 \mathrm{cde}$ & $20 \mathrm{cde}$ & $43 \mathrm{~cd}$ & $54 \mathrm{bcd}$ & $16 a b c$ \\
\hline Control (2\% ME) & 0 & $100 \mathrm{a}$ & $112 b$ & $79 b c$ & $22 \mathrm{bcd}$ & $47 \mathrm{c}$ & $55 \mathrm{bcd}$ & $14 \mathrm{~cd}$ \\
\hline \multirow[t]{2}{*}{ T. harzianum } & 50 & $85 \mathrm{a}$ & $121 \mathrm{a}$ & $104 a$ & $26 a$ & $55 \mathrm{ab}$ & $76 \mathrm{a}$ & $19 \mathrm{a}$ \\
\hline & 100 & $90 \mathrm{a}$ & $104 \mathrm{bcd}$ & $76 \mathrm{bcd}$ & $22 \mathrm{bcd}$ & $49 b c$ & $60 \mathrm{bc}$ & $16 \mathrm{abc}$ \\
\hline \multirow[t]{2}{*}{ T. pseudokoningii } & 50 & $95 \mathrm{a}$ & $106 \mathrm{bcd}$ & $78 b c$ & $23 a b c$ & 40de & $50 \mathrm{~cd}$ & $14 \mathrm{~cd}$ \\
\hline & 100 & $95 \mathrm{a}$ & $87 f$ & 64de & $17 \mathrm{e}$ & 39de & $52 \mathrm{bcd}$ & $14 \mathrm{~cd}$ \\
\hline \multirow[t]{2}{*}{ T.reesei } & 50 & $90 \mathrm{a}$ & $93 \mathrm{ef}$ & $63 \mathrm{de}$ & 19de & $43 \mathrm{~cd}$ & $63 \mathrm{abc}$ & $20 \mathrm{a}$ \\
\hline & 100 & $90 a$ & $75 \mathrm{~g}$ & $58 \mathrm{e}$ & $18 \mathrm{e}$ & $35 \mathrm{e}$ & $43 d$ & $12 \mathrm{~d}$ \\
\hline \multirow[t]{2}{*}{ T. viride } & 50 & $100 \mathrm{a}$ & $108 \mathrm{bc}$ & 74 bcde & $22 \mathrm{bcd}$ & $55 \mathrm{ab}$ & $66 a b$ & $16 \mathrm{abc}$ \\
\hline & 100 & $100 \mathrm{a}$ & 98de & $68 \mathrm{cde}$ & $20 \mathrm{cde}$ & $43 \mathrm{~cd}$ & $56 \mathrm{bcd}$ & $16 \mathrm{abc}$ \\
\hline
\end{tabular}

In a column, values with different letters show significant differences as determined by Duncan's Multiple Range Test (P $\leq 0.05)$.

ME: malt extract. 


\section{Foliar spray bioassay}

Even though a minimum effect of the different Trichoderma extracts was observed on the shoot length of A. fatua, there was a clear suppressing effect on shoot biomass of the extracts when they were sprayed $1 \mathrm{wk}$ after germination. The effect of all except $T$. viride culture filtrates was significant on shoot biomass. There was a 9-56\% reduction in shoot biomass due to foliar spray of culture filtrates on 1-wk old plants, while 2-wk old plants were comparatively tolerant to foliar spray treatments. In 2-wk old plants, foliar spray of only $T$. reesei culture filtrates significantly reduced the shoot biomass by $35 \%$ (Figure 1B).
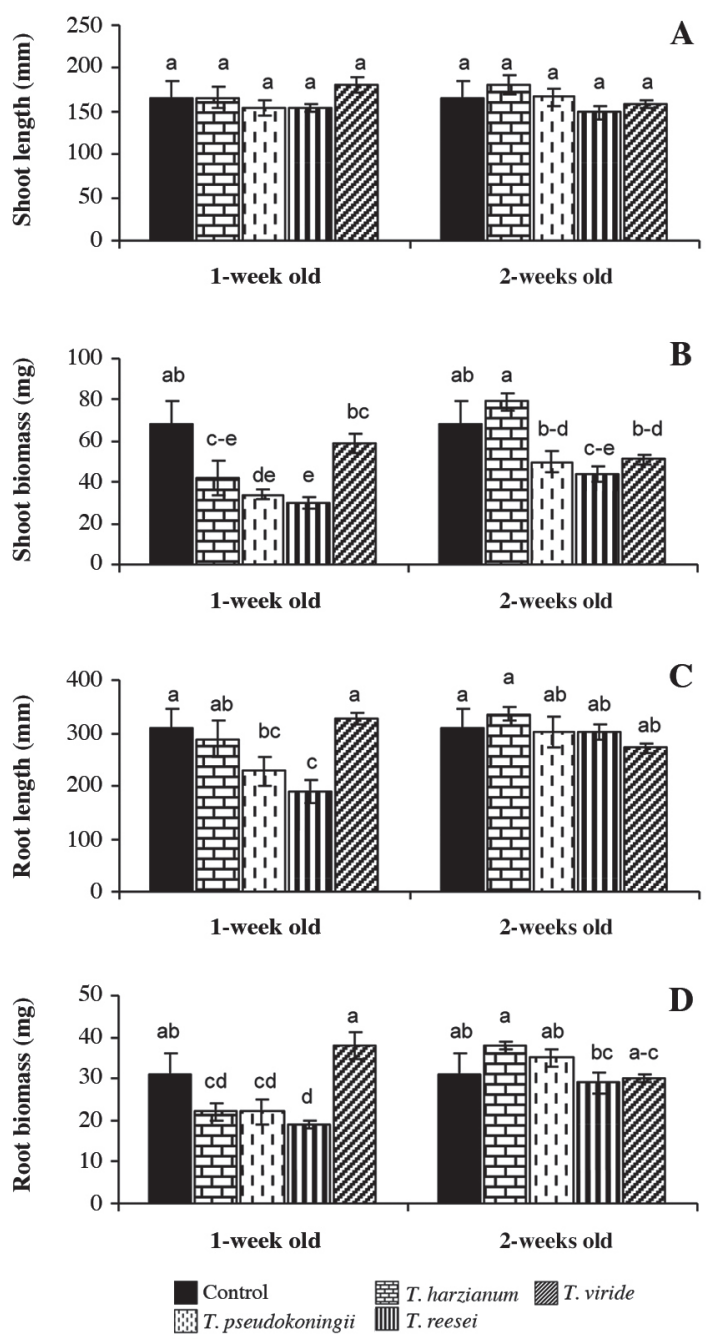

Values with the same letters show insignificant differences as determined by Duncan's Multiple Range Test at $\mathrm{P} \leq 0.05$.

Figure 1. Effect of foliar spray of cultural filtrates of four species of Trichoderma on growth of 1-wk and 2-wk-old Avena fatua plants. Vertical bars show standard errors of means of three replicates.
Root length was significantly reduced by $26 \%$ and $39 \%$ due to foliar spray of T. pseudokoningii and T. reesei, respectively, in 1-wk old A. fatua plants. Root biomass of A. fatua plants was also susceptible to foliar spray of culture filtrates at 1-wk growth stage. At this growth stage, foliar spray with culture filtrates of $T$. pseudokoningii, $T$. reesei and $T$. viride significantly reduced root biomass. None of the foliar spray treatments showed a significant effect on root length and biomass in 2-wk old plants (Figures 1C and D).

The effect of foliar spray of culture filtrates of all the four Trichoderma spp. on various parameters of root and shoot growth of wheat was insignificant (Figure 2).
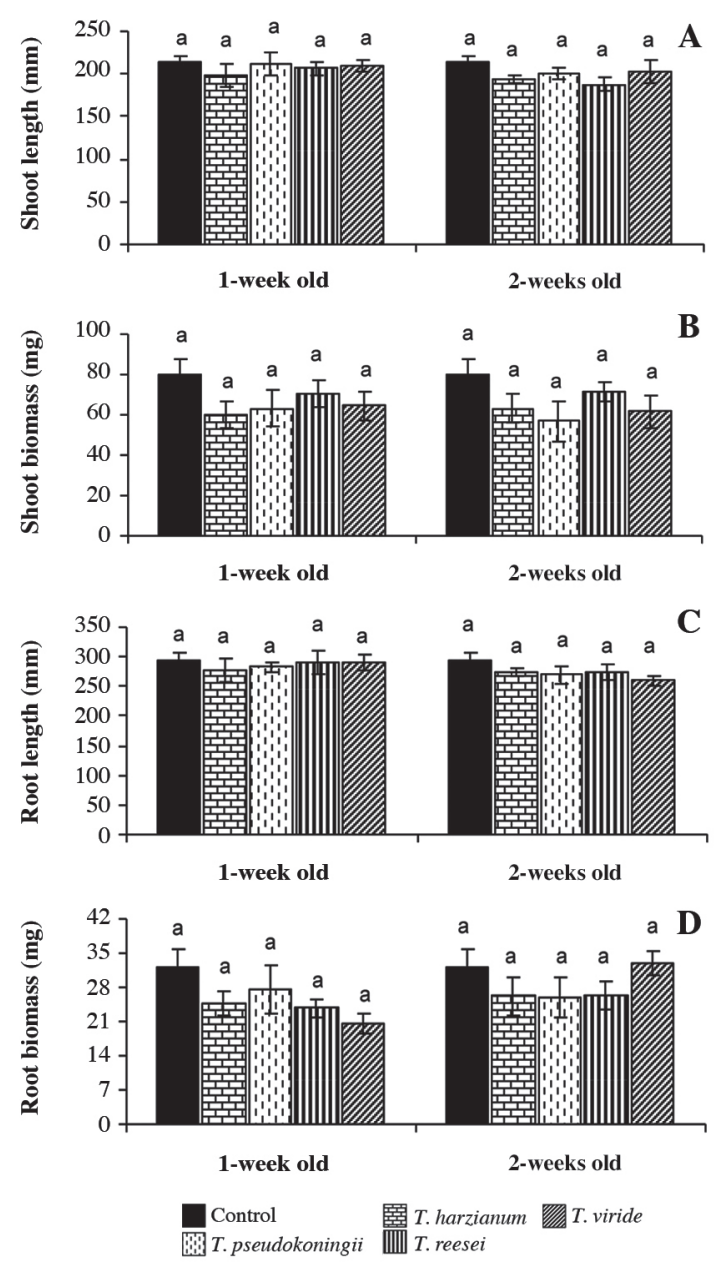

Values with the same letters show insignificant differences as determined by Duncan's Multiple Range Test at $\mathrm{P} \leq 0.05$.

Figure 2. Effect of foliar spray of cultural filtrates of four species of Trichoderma on growth of 1-wk and 2-wk-old wheat plants. Vertical bars show standard errors of means of three replicates. 


\section{DISCUSSION}

Culture filtrates of the four Trichoderma spp. tested: $T$. harzianum, T. pseudokoningii, T. reesei and T. viride, exhibited herbicidal activity against $A$. fatua . These finding are in agreement with those of the few studies carried out earlier in this field (Hutchinson, 1999; Heraux et al., 2005). The earlier studies regarding the herbicidal activity of Trichoderma spp. were restricted to the use of $T$. virens in combination with chicken manure (Hutchinson, 1999; Heraux et al., 2005). However, the present study reveals that the metabolites of other Trichoderma species also exhibit herbicidal activity. Trichoderma spp. produces a range of secondary toxic metabolites, including gliovirin, gliotoxin, viridian, and viridiol, of which viridiol is strongly phytotoxic (Jones and Hancock, 1987; Jones et al., 1988).

Metabolites of $T$. harzianum exhibited herbicidal activity against $A$. fatua in both laboratory and foliar spray bioassays. Production of toxins belonging to the trichothecene class has been reported from T. harzianum (Sivasithamparam and Ghisalberti, 1998). Trichothecenes have been proven to be phytotoxic (Harris et al., 1999). These are sesquiterpenoid epoxides and represent a large family of secondary toxic metabolites produced by a variety of filamentous fungi (Ueno, 1980). Many of the toxic properties of the trichothecenes are attributed to their ability to inhibit protein and DNA synthesis (McLaughlin et al., 1977) and to induce apoptosis in eukaryotic cells (Okumwai et al., 1999). Recently, Gallo et al. (2004) isolated and characterized a putative trichodiene synthase (tri5) gene in T. harzianum required for trichothecene biosynthesis. Another compound trichosetin, a tetramic acid-containing metabolite produced in the culture of T. harzianum, is known to exhibit phytotoxic activity (Marfori et al., 2003). Vital staining of trichosetin-treated Nicotiana tabacum BY-2 cells, with rhodamine 123, showed a weaker green fluorescence compared to controls, indicating damaging effects on mitochondria. FDA-PI staining, to determine cell viability, indicated that cells of the trichosetintreated roots were mostly dead (Marfori et al., 2003). T. harzianum also synthesises 6-pentyl- $\alpha$-pyrone (6PP), a lactone with coconut-like aroma characteristics, is used in food and pharmaceutical products (Rocha-Valadez et al., 2006). This compound is also known to exhibit phytotoxic activity (Rocha-Valadez et al., 2006), and may derive from 6PP's ability to bind to or permeate cell membranes (Poole and Whitaker, 1997).

Culture filtrates of T. pseudokoningii proved highly toxic, resulting in significant growth suppression of A. fatua plants in both the laboratory bioassay and the foliar spray trial. T. pseudokoningii culture can produce complete cellulase enzymes, namely endoglucanase, cellobiohydrolase, and $\beta$-glucosidase (Ma et al., 1990), which may be responsible for damage to the cell wall, resulting in reduced plant growth. In addition, a low molecular weight peptide, termed short fiber generating factor (SFGF), derived from the culture supernatant of T. pseudokoningii, decomposes cellulose by oxidative reaction, which differs from the hydrolysis of cellulose by cellulases. The alcoholic hydroxyl groups in cellulose can be oxidized by SFGF, which leads to destruction of the hydrogen bond network in cellulose and cleavage of glycosidic linkages. Both effects led to the depolymerization of cellulose and the formation of short fibers, further reducing groups in residual cellulose, making the cellulose substrates more susceptible to hydrolysis by cellulases (Wang et al., 2003). Certain other bioactive chemical substances, such as acetophenone derivatives $\quad 2^{\prime}, 4^{\prime}$-dihydroxy-3'-methoxymethyl-5'methylacetophenone and $2^{\prime}, 4^{\prime}-$ dihydroxy $-3^{\prime}, 5^{\prime}-$ dimethylacetophenone (Astudillo et al., 2000), Pseudokonins KL III and KL VI (Rebuffat et al., 2000), and Harzianin HK VI (Rebuffat et al., 1996) have also been isolated from culture filtrates of T. pseudokoningii, and may be responsible for the herbicidal activity of the fungus.

Culture filtrates of $T$. reesei were found to be comparatively less toxic than filtrates of $T$. harzianum and T. pseudokoningii in laboratory bioassays. Generally, only $100 \%$ culture filtrates of $T$. reesei exhibited significant effect against shoot and root growth of the target weed species and the effect of $50 \%$ culture filtrates were insignificant. However, in the foliar spray bioassay, the adverse effect of culture filtrates of $T$. reesei on 1 -wk old A. fatua plants was similar to that of culture filtrates of T. harzianum and T. pseudokoningii. Trichodermin, a member of the trichothecene toxin family - a group of sesquiterpenes, is produced by $T$. reesei in culture medium. This secondary metabolite may be responsible for herbicidal activity against $A$. fatua

\section{CONCLUSIONS}

The present study concludes that Trichoderma spp. namely $T$. harzianum, T. pseudokoningii and T. reesei produce certain secondary metabolites in the culture medium that exhibit herbicidal activity against $A$. fatua, a problematic weed of wheat. Further studies are in progress regarding the isolation and identification of potential herbicidal constituents in the culture filtrates of various tested Trichoderma species. 


\section{RESUMEN}

Alternativas de manejo de una maleza problemática de trigo Avena fatua $\mathrm{L}$. por metabolitos de Trichoderma . La avena silvestre (Avena fatua L.) es una maleza problemática del trigo (Triticum aestivum L.) en Paquistán. El presente estudio se diseñó para evaluar la actividad de filtrados de cultivos de cuatro Trichoderma spp.: T. harzianum, $T$. pseudokoningii, $T$. reesei y $T$. viride, contra esta especie. En un bioensayo de laboratorio, filtrados de cultivos originales $(100 \%)$ y diluidos $(50 \%)$ de $T$. harzianum and $T$. pseudokoningii redujeron significativamente el crecimiento de brotes y raíces de plántulas de A.fatua. Sólo los filtrados de cultivos originales de $T$. reesei exhibieron efecto significativo mientras el efecto de filtrados de $T$. viride fue insignificante contra el crecimiento de brotes y raíces de la maleza. Las concentraciones originales de filtrados de todos los cultivos de Trichoderma spp. excepto $T$. harzianum redujeron significativamente varios parámetros de crecimiento de brotes y raíces de plántulas de trigo. En el bioensayo de aspersión foliar, plántulas de $A$. fatua y trigo de 1 y 2 semanas de edad cultivadas en macetas se asperjaron con filtrados de cultivo $100 \%$ de las cuatro especies de Trichoderma tres veces con $5 \mathrm{~d}$ de intervalo cada uno. Los filtrados de cultivo de todos excepto $T$. viride redujeron significativamente la biomasa de raíces y brotes de plantas de $A$. fatua en plantas de 1 semana de edad. El efecto de la aspersión foliar sobre el crecimiento de raíces y brotes de trigo fue insignificante. El presente estudio concluye que los metabolitos de $T$. harzianum, T. reesei y $T$. pseudokoningii contienen constituyentes herbicidas para el manejo de A.fatua.

Palabras clave: herbicidas alternativos, Avena fatua, metabolitos fúngicos, Trichoderma spp.

\section{LITERATURE CITED}

Abbas, H.K., T. Tanaka, S.O. Duke, and C.D. Boyette. 1995. Susceptibility of various crops and weed species to ALL-toxin, a natural herbicide. Weed Technology 9:125-130.

Astudillo, L., G. Schmeda-Hirschmann, R. Soto, C. Sandoval, C. Afonso, M.J. González, and A. Kijjoa. 2000. Acetophenone derivatives from Chilean isolate of Trichoderma pseudokoningii Rifai. World Journal of Microbiology \& Biotechnology 16:585-587.

Evidente, A., A. Andolfi, M. Vurro, M.C. Zonno, and A. Motta. 2000. Trans-4 aminoproline, a phytotoxic metabolite with herbicidal activity produced by Ascochyta caulina. Phytochemistry 53:231-237.
Evidente, A., A. Andolfi, M. Vurro, M.C. Zonno, and A. Motta. 2005. Drazepinone, a trisubstituted tetrahydronaphthofuroazepinone with herbicidal activity produced by Drechslera siccans. Phytochemistry 66:715-721.

Evidente, A., A. Cimmino, A. Andolfi, M. Vurro, M.C. Zonno, C.L. Cantrell, and A. Motta. 2008 Phyllostictines A-D, oxazatricycloalkenones produced by Phyllosticta cirsii, a potential mycoherbicide for Cirsium arvense biocontrol. Tetrahedron 64:16121619.

Gallo, A., G. Mulè, M. Favilla, and C. Altomare. 2004. Isolation and characterisation of a trichodiene synthase homologous gene in Trichoderma harzianum. Physiological and Molecular Plant Pathology 65:1120.

Hanada, R.E., A.W.V. Pomella, W. Soberanis, L.L. Loguercio, and J.O. Pereira. 2009. Biocontrol potential of Trichoderma martiale against the blackpod disease (Phytophthora palmivora) of cacao. Biological Control 50:143-149.

Harman, G.E., C.R. Howell, A. Viterbo, I. Chet, and M. Lorito. 2004. Trichoderma species-opportunistic, avirulent plant symbionts. Nature Reviews Microbiology 2:43-56.

Harris, L.J., A.E. Desjardins, R.D. Plattner, P. Nicholson, G. Butler, and J.C. Young. 1999. Possible role of trichothecene mycotoxins in virulence of Fusarium graminearum on maize. Plant Disease 83:954-960.

Heraux, F.M.G., S.G. Hallett, and S.C. Weller. 2005. Combining Trichoderma virens-inoculated compost and a rye cover crop for weed control in transplanted vegetables. Biological Control 34:21-26.

Howell, C.R. 2003. Mechanisms employed by Trichoderma species in the biological control of plant diseases: the history and evolution of current concepts. Plant Disease 87:4-10.

Hutchinson, C.M. 1999. Trichoderma virens-inoculated composted chicken manure for biological weed control. Biological Control 16:217-222.

Javaid, A., and H. Adrees. 2009. Parthenium management by cultural filtrates of phytopathogenic fungi. Natural Product Research 23:1541-1551.

Jones, R.W., and J.G. Hancock. 1987. Conversion of the antibiotic viridian to the phytotoxin viridiol. Phytopathology 77:1240.

Jones, R.W., W.T. Lanini, and J.G. Hancock. 1988. Plant growth response to the phytotoxin viridiol produced by the fungus Gliocladium virens. Weed Science 36:683-687. 
Kovacs, K., G. Szakacs, and G.Zacchi. 2009. Comparative enzymatic hydrolysis of pretreated spruce by supernatants, whole fermentation broths and washed mycelia of Trichoderma reesei and Trichoderma atroviride. Bioresource Technology 100:1350-1357.

Ma, D.B., P.J. Gao, and Z.N. Wang. 1990. Preliminary studies on the mechanism of cellulase formation by Trichoderma pseudokoningii S-38. Enzyme and Microbial Technology 12:631-635.

Marfori, E.C., S. Kajiyama, E. Fukusaki, and A. Kobayashi. 2003. Phytotoxicity of the tetramic acid metabolite trichosetin. Phytochemistry 62:715-721.

McLaughlin, C.S., M.H. Vaughn, J.M. Campbell, C.M. Wei, M.E. Stafford, and B.S. Hansin. 1977. Inhibition of protein synthesis by trichothecenes. p. 263-273. In H.V. Rodricks, C.W. Hesseltine, and M.A. Mehlman (eds.) Mycotoxins in human and animal health. Pathotoxin Publishers, Park Forest, Illinois, USA.

Okumwai, H., N. Yoshino, Y. Suglura, M. Sugamata, E-L. Hintikka, and B. Jarvis. 1999. Trichothecenes as potent inducers of apoptosis. p. 221-231. In E. Johanning (ed.) Bioaerosols, fungi and mycotoxins: health, effects, assessment, prevention, and control. Boyd, Albany, New York, USA.

Parmar, B.S., and C. Devkumar. 1993. Botanical and biopesticides. p. 197-199. West Vill Publishing House, New Delhi, India.

Poole, P.R., and G. Whitaker. 1997. Biotransformation of 6-pentyl-2-pyrone by Botrytis cinerea in liquid cultures. Journal of Agricultural and Food Chemistry 45:249-252.

Rebuffat, S., C. Goulard, S. Hlimi, and B. Bodo. 2000. Two unprecedented natural aib-peptides with the (Xaa-Yaa-Aib-Pro) motif and an unusual C-terminus: Structures, membrane-modifying and antibacterial properties of pseudokonins KL III and KL VI from the fungus Trichoderma pseudokoningii. Journal of Peptide Science 6:519-533.
Rebuffat, S., S. Hlimi, Y. Prigent, C Goulard, and B. Bodo. 1996. Isolation and structural elucidation of the 11-residue peptaibol antibiotic, harzianin HK VI. Journal of the Chemical Society Perkin Transactions I 16:2021-2027.

Rocha-Valadez, J.A., M. Estrada, E. Galindo, and L. Serrano-Carreón. 2006. From shake flasks to stirred fermentors: Scale-up of an extractive fermentation process for 6-pentyl- $\alpha$-pyrone production by Trichoderma harzianum using volumetric power input. Postharvest Biology and Technology 41:13471352.

Sadhasivam, S., S. Savitha, K. Swaminathan, and F.H.Lin. 2008. Production, purification and characterization of mid-redox potential laccase from a newly isolated Trichoderma harzianum WL1. Process Biochemistry 43:736-742.

Sahebani, N., and N. Hadavi. 2008. Biological control of the root-knot nematode Meloidogyne javanica by Trichoderma harzianum. Soil Biology and Biochemistry 40:2016-2020.

Sivasithamparam, K., and E.L. Ghisalberti. 1998. Secondary metabolism in Trichoderma and Glioclaudium. p. 139-191. In Kubicek, C.P., and G.E. Harman (eds.) Trichoderma and Glioclaudium. Vol. 1. Taylor \& Francis, London, UK.

Steel, R.G.D., and J.H. Torrie. 1980. Principles and procedures of statistics. A biometrical approach. $2^{\text {nd }}$ ed. McGraw Hill Book, New York, USA

Ueno, Y. 1980. Trichothecene mycotoxins: mycology, chemistry, and toxicology. Advances in Nutritional Research 24:301-353.

Wang, W., J. Liu, G.J. Chen, Y.S. Zhang, and P.J. Gao. 2003. Function of a low molecular weight peptide from Trichoderma pseudokoningii S38 during cellulose biodegradation. Current Microbiology 46:371-379. 